\title{
ANALISIS KINERJA GUDANG DENGAN PENDEKATAN KEY PERFORMANCE INDICATOR (KPI) DAN ANALITYCAL HIERARCHY PROCESS (AHP)
}

\author{
Qurtubi, R. Abdul Jalal dan Wihdah Safitri \\ Program Studi Teknik Industri, Fakultas Teknologi Industri, Universitas Islam Indonesia, Yogyakarta \\ e-mail: qurtubi@uii.ac.id
}

\begin{abstract}
ABSTRAK
Perkembangan industri yang sangat cepat mengharuskan perusahaan mampu mengelola internalnya supaya tidak kalah dari perusahaan kompetitor. Di antara masalah utama dalam pengelolaan internal perusahaan adalah manajemen pergudangan. Tujuan penelitian ini untuk mengevaluasi kinerja dari gudang PT XYZ dan mengetahui faktor apa saja yang paling berpengaruh terhadap kinerja gudang perusahaan, serta mengetahui apakah gudang tersebut menguntungkan atau merugikan perusahaan. PT XYZ adalah perusahaan yang bergerak dalam bidang pengelolaan usaha eksploitasi dan produksi minyak dan gas. Metode yang digunakan untuk mengevaluasi kinerja adalah KPI warehouse, sebuah ukuran berskala dan kuantitatif. Untuk mengetahui variabel mana yang berperan penting dalam peningkatan performansi gudang, menggunakan variabel key performance indicator yaitu receiving, putaway, storage, order picking dan shipping dengan metode AHP. Hasilnya menunjukkan score terendah pada fungsi shipping dengan score KPI sebesar 301. Hal ini disebabkan faktor utilization, yaitu pada saat material kategori A yakni tawas, kaporit, oxygen dan accetylene masing-masing dikirim ke user, pengiriman hanya berkuantitas sehingga area luas pengiriman banyak yang kosong dan mengakibatkan pemborosan pada proses pengiriman.
\end{abstract}

Kata Kunci: AHP, kinerja gudang, KPI.

\begin{abstract}
Rapid industrial development obligates a company to be able to manage its internal management to compete with other competitors. One of the main issues that emerge in company's internal management is warehouse management. The objective of this research is to evaluate the performance of warehouse in PT. XYZ as well as to discover the most influenced factor towards performance of company's warehouse and to identify whether the warehouse contributes the benefits of cost the lost for the company. PT. XYZ is a company that works in the oil and gas exploitation and production. The method that applied to evaluate the performance is warehouse KPI, a scaled and quantitative measurement. To find out which variables that play important role in enhancing warehouse performance, variables of key performance indicators are employed, such as receiving, put-away, storage, order picking and shipping by using AHP method. The results indicated the lowest score for shipping function with KPI score of 301. It caused by utilization factors, for materials on category A, which are alum, chlorine, oxygen and acetylene that each will be sent to user. The delivery is only based on quantity; hence empty space areas for delivery are discovered. It leads to waste on delivery process.
\end{abstract}

Keywords: AHP, warehouse performance, KPI.

\section{PENDAHULUAN}

Perkembangan industri meningkat pesat, agar perusahaan bisa mempertahankan posisi pasar dalam persaingan industri dibutuhkan pengelolaan terhadap sistem rantai pasok perusahaan. Pengelolaan sistem rantai pasok ini dinamakan supply chain management. Pada sistem rantai pasok, sistem logistik merupakan satu di antara yang mempunyi peran penting, dan di dalam sistem logistik pergudangan memiliki peran pokok. Banyak perusahaan sekarang ini yang mempunyai gudang atau warehouse, yaitu area yang berfungsi untuk penyimpanan bahan baku (raw material), barang setengah jadi (working-process), dan barang jadi (finished goods), gudang juga menyimpan barang untuk produksi atau hasil produksi dalam rentang waktu dan jumlah tertentu yang selanjutnya berdasarkan permintaan didistribusikan ke lokasi yang dituju. Oleh karena itu gudang perusahaan seharusnya dikelola dengan baik, mengingat perannya yang penting. Perusahaan yang mempunyai gudang harus memantau dan mengukur kondisi atau performansi gudang 
yang dikelolanya sehingga perusahaan tidak mengalami kerugian.

Salah satu metode yang bisa dipakai untuk menghitung dan mengukur performansi gudang adalah Key Performance Indicator (KPI). KPI ini dipakai perusahaan untuk mengukur atau membandingkan kinerja guna memenuhi tujuan strategis dan operasional. Selanjutnya dibutuhkan Analytical Hierarchy Process (AHP) yang bisa dipakai untuk menentukan tingkat kepentingan dari variabel yang dipakai mengukur KPI sehingga dapat diketahui variabel yang berperan penting dalam peningkatan performansi. Tujuan penelitian ini adalah untuk mengevaluasi kinerja gudang dan mengetahui faktor apa saja yang paling berpengaruh terhadap kinerja gudang perusahaan, serta mengetahui apakah gudang tersebut menguntungkan atau merugikan perusahaan.

PT XYZ adalah sebuah perusahaan yang menjalankan kegiatan di sektor hulu bidang minyak dan gas bumi, meliputi eksplorasi dan produksi. Dalam melaksanakan tujuan utamanya, perusahaan memiliki sistem logistik yang berfungsi menyimpan produk dan perlengkapan produksi lainnya serta menyediakan informasi mengenai status dan keadaan material/produk yang disimpan di gudang sehingga informasi itu mudah diakses oleh yang berkepentingan. Fungsi gudang PT XYZ adalah tempat penyimpanan material yang diperlukan oleh user dan untuk kegiatan produksi seperti pengeboran yang menghasilkan gas, minyak, dan air. Material tersebut meliputi material rutin seperti pipa, tawas, kaporit, oxygen, accetylene, dan sebagainya. Mengingat pentingnya peran gudang dalam kegiatan produksi perusahaan, evaluasi atau pengukuran kinerja dari gudang sangat diperlukan oleh perusahaan untuk mengetahui apakah gudang telah berkontribusi baik bagi perusahaan atau merugikan untuk perusahaan, dan dapat mengetahui faktor apa saja yang paling memberikan pengaruh terhadap kinerja gudang.

\section{METODE PENELITIAN}

Bagian ini membahas tentang metode penelitian yang mencakup sumber data, teknik pengumpulan data, dan alur/tahapan penelitian.

\section{Sumber Data}

Data yang dikumpulkan dalam penelitian ini adalah data primer berupa data proses bisnis yang ada di pergudangan PT XYZ, yaitu data proses bisnis pada saat empat material rutin yaitu tawas, kaporit, oxygen, dan acetylene datang sampai didistribusikan ke user, data tersebut berupa SOP, layout, kinerja, biaya, produktifitas, dan utilisasi pada setiap proses pergudangan perusahaan. Selain itu data skunder, data bersumber dari literatur yang berhubungan dengan penelitian, seperti konsep pengukuran kinerja gudang menggunakan KPI dan AHP.

\section{Teknik Pengumpulan Data}

Data-data tersebut dikumpulkan menggunakan beberapa metode, yaitu: observasi, wawancara, studi literatur, dan pendapat pakar.

\section{Alur/Tahapan Penelitian}

Alur/tahapan dalam penelitian ini adalah mengidentifikasi proses bisnis gudang, observasi dan wawancara langsung kepada pakar, mengolah data KPI, menormalisasi data, membobotkan data dengan AHP, menganalisis hasil pengolahan data, dan menarik kesimpulan.

\section{HASIL DAN PEMBAHASAN}

Bagian ini membahas hasil dan pembahasan yang meliputi Key Performance Indicator, SNORM (Standar Normalisasi), dan Analytical Hierarcy Process (AHP).

\section{Key Performance Indicator (KPI)}

Referensi [1] mendefinisikan KPI sebagai ukuran berskala dan kuantitatif yang digunakan untuk mengevaluasi kinerja organisasi dalam tujuan mencapai target organisasi. Menurut [2] KPI adalah sekumpulan pengukuran yang diciptakan terfokus kepada aspek kinerja organisasi. Sedangkan, menurut [3] KPI merupakan sebuah pengukuran yang menilai bagaimana sebuah industri atau perusahaan mengeksekusi visi strategisnya. Visi strategis yang dimaksud merujuk kepada bagaimana strategi organisasi secara interaktif terintegrasi dalam strategi organisasi secara menyeluruh. Sementara itu [4] berpendapat, KPI adalah 
ukuran yang bersifat kuantitatif dan bertahap bagi perusahaan serta memiliki berbagai perspektif dan berbasiskan data konkret, dan menjadi titik awal penentuan tujuan dan penyusunan strategi organisasi. Indicator KPI yang digunakan dalam penelitian ini berdasarkan warehouse key performance indicator, variabel yang digunakan variabel key performance indicator [5], dalam variabel tersebut dilakukan observasi, wawancara dan pendapat pakar melalui pertanyaan-pertanyaan untuk setiap material sebagaimana Tabel 1 .

Tabel 1. Pertanyaan Kepada Pakar

\begin{tabular}{|c|c|c|c|c|}
\hline Receiving & Put-away & Storage & Order-picking & Shipping \\
\hline $\begin{array}{l}\text { Berapa biaya } \\
\text { receiving } \\
\text { cost/line } \\
\end{array}$ & $\begin{array}{l}\text { Biaya receiving } \\
\text { cost per line }\end{array}$ & $\begin{array}{l}\text { Biaya storage } \\
\text { space cost per } \\
\text { item }\end{array}$ & $\begin{array}{l}\text { Picking cost per } \\
\text { order line }\end{array}$ & $\begin{array}{l}\text { Shipping cost per } \\
\text { customer order }\end{array}$ \\
\hline $\begin{array}{l}\text { Berapa jumlah } \\
\text { stok yang dapat } \\
\text { dibongkar per } \\
\text { operator per jam? }\end{array}$ & $\begin{array}{l}\text { Berapa jumlah } \\
\text { stok yang dapat } \\
\text { dipindahkan per } \\
\text { operator per jam? }\end{array}$ & $\begin{array}{l}\text { Berapa ukuran } \\
\text { inventori dalam } \\
\mathrm{m}^{2} \text { pada setiap } \\
\text { penyimpanan } \\
\text { stok barang? } \\
\end{array}$ & $\begin{array}{l}\text { Berapa jumlah } \\
\text { order stok barang } \\
\text { yang dapat } \\
\text { diambil per jam? }\end{array}$ & $\begin{array}{l}\text { Berapa jumlah } \\
\text { order stok barang } \\
\text { yang dikirim per } \\
\text { jam? }\end{array}$ \\
\hline $\begin{array}{l}\text { Berapa } \\
\text { persentase } \\
\text { penggunaan area } \\
\text { penerimaan? (\%) }\end{array}$ & $\begin{array}{l}\text { Berapa } \\
\text { persentase } \\
\text { penggunaan alat } \\
\text { dan jumlah } \\
\text { pekerja saat put- } \\
\text { away? (\%) }\end{array}$ & $\begin{array}{l}\text { Berapa } \\
\text { persentase } \\
\text { penggunaan area } \\
\text { penyimpanan } \\
\text { pada setiap stok } \\
\text { barang? (\%) }\end{array}$ & $\begin{array}{l}\text { Berapa } \\
\text { persentase } \\
\text { penggunaan alat } \\
\text { dan jumlah } \\
\text { pekerja saat } \\
\text { pengambilan } \\
\text { barang? (\%) }\end{array}$ & $\begin{array}{l}\text { Berapa } \\
\text { persentase } \\
\text { penggunaan area } \\
\text { pengiriman? (\%) }\end{array}$ \\
\hline $\begin{array}{l}\text { (Berapa area } \\
\text { penerimaan } \\
\text { keseluruhan dan } \\
\text { area yang } \\
\text { digunakan untuk } \\
\text { bongkar muat) }\end{array}$ & $\begin{array}{l}\text { (Jumlah alat } \\
\text { keseluruhan dan } \\
\text { jumlah alat yang } \\
\text { digunakan pada } \\
\text { saat pemindahan } \\
\text { stok barang) }\end{array}$ & $\begin{array}{l}\text { (Jumlah area } \\
\text { penyimpanan dan } \\
\text { area yang } \\
\text { digunakan untuk } \\
\text { menyimpan stok } \\
\text { barang) }\end{array}$ & $\begin{array}{l}\text { (Jumlah seluruh } \\
\text { alat dan jumlah } \\
\text { alat yang } \\
\text { digunakan untuk } \\
\text { mengambil serta } \\
\text { memindahkan } \\
\text { stok barang) }\end{array}$ & $\begin{array}{l}\text { (Luas seluruh } \\
\text { area pengiriman } \\
\text { dan luas area } \\
\text { yang digunakan } \\
\text { untuk } \\
\text { pengiriman) }\end{array}$ \\
\hline $\begin{array}{l}\text { Berapa } \\
\text { persentase } \\
\text { kesesuaian } \\
\text { barang yang } \\
\text { diterima dengan } \\
\text { purchase order? } \\
(\%)\end{array}$ & $\begin{array}{l}\text { Berapa } \\
\text { persentase } \\
\text { kualitas } \\
\text { pemindahan } \\
\text { barang? (\%) } \\
\text { (Berapa jumlah } \\
\text { barang yang } \\
\text { dipindahkan dan } \\
\text { jumlah kerusakan } \\
\text { barang saat } \\
\text { pemindahan) } \\
\end{array}$ & $\begin{array}{l}\text { Berapa } \\
\text { persentase area } \\
\text { penyimpanan } \\
\text { dengan tidak } \\
\text { adanya } \\
\text { ketidaksesuaian } \\
\text { penyimpanan } \\
\text { inventori? (\%) }\end{array}$ & $\begin{array}{l}\text { Berapa } \\
\text { persentase } \\
\text { kualitas } \\
\text { pengambilan } \\
\text { barang (\%) }\end{array}$ & $\begin{array}{l}\text { Berapa } \\
\text { persentase } \\
\text { kualitas } \\
\text { pengiriman } \\
\text { barang? (\%) }\end{array}$ \\
\hline $\begin{array}{l}\text { (Berapa jumlah } \\
\text { produk setiap } \\
\text { order dan berapa } \\
\text { produk yang } \\
\text { cacat) }\end{array}$ & $\begin{array}{l}\text { Berapa lama } \\
\text { waktu untuk } \\
\text { setiap proses } \\
\text { pemindahan } \\
\text { barang? }\end{array}$ & $\begin{array}{l}\text { (Luas area } \\
\text { penyimpanan dan } \\
\text { luas area dengan } \\
\text { kesalahan } \\
\text { meletakkan } \\
\text { barang) }\end{array}$ & $\begin{array}{l}\text { (Berapa jumlah } \\
\text { stok barang yang } \\
\text { diambil dan } \\
\text { jumlah kerusakan } \\
\text { barang saat } \\
\text { pengambilan) }\end{array}$ & $\begin{array}{l}\text { (Berapa jumlah } \\
\text { stok barang yang } \\
\text { dikirim dan } \\
\text { jumlah kerusakan } \\
\text { barang saat } \\
\text { pengiriman) }\end{array}$ \\
\hline
\end{tabular}


Lanjutan Tabel 1. Pertanyaan Kepada Pakar

\begin{tabular}{lllll}
\hline \multicolumn{1}{c}{ Receiving } & \multicolumn{1}{c}{ Put-away } & \multicolumn{1}{c}{ Storage } & \multicolumn{1}{c}{ Order-picking } & \multicolumn{1}{c}{ Shipping } \\
\hline Berapa lama & (Mulai dari & Berapa lama & Berapa lama & (Mulai dari \\
waktu untuk & identifikasi & waktu & waktu proses & setelah barang \\
setiap proses & produk, & penyimpanan & pengambilan & diambil sampai \\
penerimaan & identifikasi & inventori atau & barang pada & dimuat ke dalam \\
barang? (Mulai & lokasi & persediaan stok & setiap order? & truk) \\
dari pemeriksaan & penyimpanan, & barang sampai & & \\
dokumen, & pemindahan, dan & barang keluar? & & \\
bongkar muat, & update stok) & & & \\
pemeriksaan & & & & \\
mutu/inspeksi) & & & & \\
\hline
\end{tabular}

Sumber: [5], diolah.

\section{SNORM (Standar Normalisasi)}

Menurut [6] normalisasi adalah tahapan-tahapan yang masing-masing berhubungan dengan bentuk normal. Sedangkan menurut [7], normalisasi adalah proses pengelompokan elemen data menjadi tabel-tabel yang menunjukan entity dan relasinya. Sementara itu [8] berpendapat, normalisasi adalah suatu teknik yang menstrukturkan data dalam cara tertentu untuk membantu mengurangi atau mencegah timbulnya masalah yang berhubungan dengan pengolahan data dalam database.

Pada pengukuran setiap bobot indikator dikonversikan ke dalam interval nilai tertentu yaitu 0 sampai 100 . Nol (0) diartikan paling jelek dan seratus (100) diartikan paling baik. Dengan demikian parameter dari setiap indikator adalah sama, setelah itu didapatkan suatu hasil yang dapat dianalisis.
Tabel 2. Sistem Monitoring Indikator Performasi

\begin{tabular}{cc}
\hline $\begin{array}{c}\text { Sistem } \\
\text { monitoring }\end{array}$ & Indikator performansi \\
\hline$<40$ & Poor \\
$40-50$ & Marginal \\
$50-70$ & Average \\
$70-90$ & Good \\
$>90$ & Excellent \\
\hline
\end{tabular}

Sumber: [9]

Setelah diperoleh data dari berbagai metode pengumpulan data, berdasarkan hasil pertanyaan untuk empat material tersebut diperoleh sebuah jawaban yang telah diolah menjadi data rata-rata, kemudian dilakukan normaliasi terhadap data-data tersebut untuk mendapatkan skor akhir dari proses bisnis gudang PT XYZ sebagaimana ditunjukkan pada Tabel 3.

Tabel 3. Normalisasi

\begin{tabular}{clccccc}
\hline \multicolumn{7}{c}{ Receiving } \\
\hline No & Measure & Unit & Current & Min & Max & Score \\
\hline 1 & Financial & Rp & 18.182 & 15.000 & 20.000 & 63,64 \\
2 & Productivity & pcs/operator/jam & 17,5 & 11,25 & 17.5 & 100 \\
3 & Utilization & $\%$ & 82,25 & 57,5 & 100 & 60 \\
4 & Quality & $\%$ & 99 & 95 & 100 & 80 \\
5 & Cycle Time & Menit & 30 & 15 & 32,25 & 90,63 \\
\hline \multicolumn{7}{c}{ Total Score } \\
\hline
\end{tabular}


Lanjutan Tabel 3. Normalisasi

\begin{tabular}{|c|c|c|c|c|c|c|}
\hline \multicolumn{7}{|c|}{ Put-Away } \\
\hline No & Measure & Unit & Current & Min & $\operatorname{Max}$ & Score \\
\hline 1 & Financial & $\mathrm{Rp}$ & 9.091 & 5.000 & 10.000 & 81,82 \\
\hline 2 & Productivity & pcs/operator/jam & 17,5 & 10 & 20 & 75 \\
\hline 3 & Utilization & $\%$ & 100 & 12,5 & 100 & 100 \\
\hline 4 & Quality & $\%$ & 99 & 95 & 100 & 80 \\
\hline 5 & Cycle Time & Menit & 30 & 15 & 30 & 100 \\
\hline \multicolumn{6}{|c|}{ Total Score } & 436,820 \\
\hline \multicolumn{7}{|c|}{ Storage } \\
\hline No & Measure & Unit & Current & Min & Max & Score \\
\hline 1 & Financial & $\mathrm{Rp}$ & 909,1 & 500 & 909,1 & 100 \\
\hline 2 & Productivity & pcs/operator/jam & 15 & 3.5 & 15 & 100 \\
\hline 3 & Utilization & $\%$ & 79 & 50 & 100 & 58 \\
\hline 4 & Quality & $\%$ & 99 & 95 & 100 & 80 \\
\hline 5 & Cycle Time & Menit & 7 & 5 & 14 & 22,22 \\
\hline \multicolumn{6}{|c|}{ Total Score } & 360,220 \\
\hline \multicolumn{7}{|c|}{ Order Picking (Picking \& Packing) } \\
\hline No & Measure & Unit & Current & Min & $\operatorname{Max}$ & Score \\
\hline 1 & Financial & $\mathrm{Rp}$ & $3.036,39$ & 2.000 & $3.152,3$ & 92,273 \\
\hline 2 & Productivity & pcs/operator/jam & 8 & 3 & 8,5 & 87,5 \\
\hline 3 & Utilization & $\%$ & 87,5 & 12,5 & 100 & 75 \\
\hline 4 & Quality & $\%$ & 99 & 95 & 100 & 80 \\
\hline 5 & Cycle Time & Menit & 10 & 5 & 15 & 50,00 \\
\hline \multicolumn{6}{|c|}{ Total Score } & 384,770 \\
\hline \multicolumn{7}{|c|}{ Shipping } \\
\hline No & Measure & Unit & Current & Min & $\operatorname{Max}$ & Score \\
\hline 1 & Financial & $\mathrm{Rp}$ & $5.856,12$ & 4.000 & 6.375 & 74,20 \\
\hline 2 & Productivity & pcs/operator/jam & 34,5 & 25 & 50 & 45 \\
\hline 3 & Utilization & $\%$ & 51,25 & 40 & 100 & 19,17 \\
\hline 4 & Quality & $\%$ & 99 & 95 & 100 & 80 \\
\hline 5 & Cycle Time & Menit & 8,75 & 4,5 & 10 & 82,14 \\
\hline \multicolumn{6}{|c|}{ Total Score } & 300,510 \\
\hline
\end{tabular}

Dari hasil Tabel 3 dapat disimpulkan, skor akhir untuk proses bisnis gudang PT. XYZ dengan perputaran material rutin berupa tawas, kaporit, oxygen, accetylene sebagaimana ditunjukkan pada Tabel 4.

Berdasarkan hasil perhitungan skor akhir untuk gudang PT XYZ menggunakan indikator KPI warehouse dan telah dinormalisasi, diperoleh skor untuk kinerja PT XYZ sebesar 375.32, dengan skor tertinggi dimiliki oleh proses put-away 436.82. Faktor terbesar yang menjadikan skor proses ini tinggi karena faktor utilization dan cycle time dari proses put-away yang telah memanfaatkan penggunaan alat angkut dengan baik serta waktu proses receiving dengan tepat. Skor terendah dimiliki oleh proses shipping sebesar 300.51. Hal ini dibuktikan bahwa, faktor yang mempengaruhi rendahnya skor proses tersebut dikarenakan faktor pada faktor utilization yang sangat rendah, yaitu pada saat proses shipping penggunaan luas area untuk pengiriman material sangat kecil dari total luas area yang ada, hal ini dapat menimbulkan pemborosan dalam segi biaya pengiriman ke user. 
Tabel 4. Skor Akhir

\begin{tabular}{cc}
\hline \multicolumn{2}{c}{ Key Performance Indicator (KPI) } \\
\hline & Score \\
Receiving & 394,265 \\
Put-Away & 436,82 \\
Storage & 360,22 \\
Order Picking & 384,77 \\
Shipping & 300,51 \\
Skor Akhir & $1.876,59$ \\
Rata-rata & 375,32 \\
\hline
\end{tabular}

\section{Analytical Hierarchy Process (AHP)}

Analytical Hierarchy Process (AHP) adalah suatu model yang luwes yang memungkinkan kita mengambil keputusan dengan mengkombinasikan pertimbangan dan nilai-nilai pribadi secara logis [10]. AHP merupakan cara pengambilan keputusan yang paling efektif atas berbagai persoalan yang kompleks dengan jalan menyederhanakan dan mempercepat pencarian solusi atas persoalan yang kita alami. AHP dapat digunakan juga untuk menentukan kepentingan dari suatu variabel, dalam menilai tingkat kepentingan suatu elemen terhadap elemen lainnya diperoleh skala penilaian perbandingan berpasangan yang menentukan intensitas kepentingan elemen tersebut [11].

AHP digunakan dalam pembobotan masing-masing KPI untuk mengetahui KPI yang memiliki bobot terbesar dan terkecil. Dimana fungsinya untuk mengetahui tingkat kepentingan dari variabel yang telah diberi bobot, variabel ini digunakan dalam key performance indicator sehingga dapat diketahui variabel mana yang berperan penting dalam peningkatan performansi perusahaan. Dalam penelitian ini, pengukuran KPI memiliki variabel yang dapat menjadi tolak ukur untuk mengetahui variabel mana yang berperan penting dalam meningkatkan kinerja gudang.

Tabel 5. Hasil AHP

\begin{tabular}{|c|c|c|c|c|}
\hline \multicolumn{5}{|c|}{ Pairwise Comparison KPI Receiving } \\
\hline No & Measure & Eugen Vector & SNORM & Nilai Akhir \\
\hline 1 & Financial & 0,195 & 63,64 & 12,410 \\
\hline 2 & Productivity & 0,263 & 100,00 & 26,267 \\
\hline 3 & Utilization & 0,195 & 60,00 & 11,710 \\
\hline 4 & Quality & 0,318 & 80,00 & 25,438 \\
\hline \multirow[t]{2}{*}{5} & Cycle Time & 0,029 & 90,63 & 2,643 \\
\hline & & & Total & 78,469 \\
\hline \multicolumn{5}{|c|}{ Pairwise Comparison KPI Put-Away } \\
\hline No & Measure & Eugen Vector & SNORM & Nilai Akhir \\
\hline 1 & Financial & 0,201 & 81,82 & 16,426 \\
\hline 2 & Productivity & 0,182 & 75,00 & 13,619 \\
\hline 3 & Utilization & 0,172 & 100,00 & 17,172 \\
\hline 4 & Quality & 0,320 & 80,00 & 25,562 \\
\hline \multirow[t]{2}{*}{5} & Cycle Time & 0,126 & 100,00 & 12,642 \\
\hline & & & Total & 85,420 \\
\hline \multicolumn{5}{|c|}{ Pairwise Comparison KPI Storage } \\
\hline No & Measure & Eugen Vector & SNORM & Nilai Akhir \\
\hline 1 & Financial & 0,070 & 100,00 & 7,000 \\
\hline 2 & Productivity & 0,210 & 100,00 & 21,001 \\
\hline 3 & Utilization & 0,174 & 58,00 & 10,072 \\
\hline 4 & Quality & 0,210 & 80,00 & 16,801 \\
\hline \multirow[t]{2}{*}{5} & Cycle Time & 0,336 & 22,22 & 7,474 \\
\hline & & & Total & 62,348 \\
\hline
\end{tabular}


Lanjutan Tabel 5. Hasil AHP

\begin{tabular}{clccc}
\multicolumn{5}{c}{ Pairwise Comparison KPI Order-Picking } \\
\hline No & Measure & Eugen Vector & SNORM & Nilai Akhir \\
1 & Financial & 0,067 & 92,27 & 6,148 \\
2 & Productivity & 0,277 & 87,50 & 24,265 \\
3 & Utilization & 0,228 & 75,00 & 17,081 \\
4 & Quality & 0,302 & 80,00 & 24,141 \\
5 & Cycle Time & 0,127 & 50,00 & 6,327 \\
\hline \multicolumn{5}{c}{ Total } \\
\hline No & Measure & Eugen Vector & 77,963 \\
1 & Financial & 0,209 & SNORM & Nilai Akhir \\
2 & Productivity & 0,197 & 74,20 & 15,480 \\
3 & Utilization & 0,201 & 45,00 & 8,885 \\
4 & Quality & 0,358 & 19,17 & 3,855 \\
5 & Cycle Time & 0,035 & 80,00 & 28,629 \\
\hline & & 82,14 & 2,869 \\
\hline
\end{tabular}

Berdasarkan hasil pembobotan menggunakan AHP sebagaimana ditunjukkan pada Tabel 5, diketahui pada proses receiving, put-away, order picking, dan shipping memiliki kriteria terbesar pada quality dalam hal ini membuktikan bahwa proses gudang tersebut, kualitas dari setiap proses sangat baik. Sedangkan untuk proses storage bobot tertinggi dimiliki oleh kriteria cycle time dalam hal ini dibuktikan bahwa perputaran material yang terdapat dalam gudang tersebut sangat baik.

\section{KESIMPULAN}

Berdasarkan hasil perhitungan dan pembahasan di atas dapat disimpulkan bahwa pada perhitungan KPI diketahui indikator atau proses yang memiliki skor terendah ada pada shipping sebesar 300,51, karena faktor utama yaitu utilization hanya memanfaatkan luas area pengiriman sebesar $51.29 \%$ dari total kesuluruhan. Rata-rata setiap proses shipping, gudang mengirim material untuk user hanya berkuantitas sedikit, hal ini dapat merugikan perusahaan karena pemborosan biaya dalam pengiriman. Skor tertinggi ada pada put-away sebesar 436,82. Faktor utama yang menyebabkan skor tertinggi karena pada utilization memanfaatkan alat pengangkut material dengan baik sebesar 100\%. Dalam perhitungan AHP diketahui pada proses receiving, put-away, order picking dan shipping memiliki kesamaan bobot terbesar yaitu pada kriteria quality. Hal ini sangat baik bagi perusahaan karena kualitas material dari proses barang datang sampai dikirim ke user sangat terjaga kelengkapannya. Sedangkan untuk proses storage memiliki bobot tertinggi pada kriteria cycle time, artinya perputaran material yang terdapat pada gudang PT XYZ khususnya pada material tawas, kaporit, oxygen dan accetylene sangat baik.

\section{DAFTAR PUSTAKA}

[1]. Banerjee, J., Buoti, C., 2012, General specifications of KPIs, International Telecomunnication Union.

[2] Parmenter, D., 2007, Key Performance Indicators : Developing, Implementing and Using Winning KPI's, John WIley \& Sons Inc, New Jersey.

[3]. Warren, C.S., Duchac, J., 2011, Accounting, Volume 3, Cengage Learning, Singapore.

[4]. Iveta, G., 2012, Human Resources Key Performance Indikator, Journal Of Competitiveness, 4 (1): 177-128.

[5]. Frazelle, E.H., 2002, Wordl Class Warehousing and Material Handling, McGraw Hill Professional.

[6]. Nugroho, A., 2011, Perancangan dan Implementasi Sistem Basis Data, Media Komputindo, Jakarta. 
[7]. Paillin, D.B., 2012, Perancangan Sistem Informasi Penjualan pada Toko Ribo Jaya Ambon, Universitas Pattimura, Ambon.

[8]. Sutabri, T., 2005, Sistem Informasi Manajemen, Jakarta.

[9]. Trienekens, J.H., Hvolby, H.H., 2000, Performance Measurment and Improvement in Supply Chain, CINET Conference.

[10]. Saaty, T.L., 1993, Pengambilan Keputusan Bagi Para Pemimpin, Proses Hirarki Analitik untuk pengambilan Keputusan dalam Situasi yang Kompleks, PT Pustaka Binaman Pressindo, Jakarta.

[11]. Saaty, T.L., 1998, Multicriteria Decision Making - The Analytic Hierarchy Process, Eta Service Typesetters, USA. 